\title{
Transparency in the Procurement of Goods and Services through E-Procurement at LPSE, Banda Aceh City
}

\author{
Taufik $^{1}$, Muazzinah $^{2}$, Al-Adly Darniyus ${ }^{3}$ \\ \{taufik.fisip@ar-raniry.ac.id ${ }^{1}$, muazzinah@ar-raniry.ac.id ${ }^{2}$, aladlydarniyus@gmail.com ${ }^{3}$ \}
}

UIN Ar-Raniry Banda Aceh, Indonesia ${ }^{1,2,3}$

\begin{abstract}
The transition of a manual system to an electronic system in the procurement of goods and services is still a problem. One of them is an indication of intervention between auction organizers and the power of budget users. This study aims to describe the transparency of the procurement of goods and services through e-procurement at the LPSE in Banda Aceh City. This study uses qualitative research methods with descriptive analysis techniques. The results of the study indicate that the implementation of e-procurement in the LPSE of Banda Aceh City has not been said to be transparent. This is indicated by the lack of cooperation with the media and non-government institutions, because information related to the auction was submitted through the website. Whereas other indicators have been going well, such as (a) clear information about procedures, (b) ease of access to information, (c) existence of complaints mechanism, (d) cooperation with media and nongovernment institutions, and (e) existence access to accurate and timely information. However, there are still obstacles faced by companies participating in tenders related to the use of electronic procurement applications. This is due to the lack of capacity of human resources owned by the company. Therefore, the Banda Aceh LPSE is encouraged to foster the company not only to the extent of socialization but the presence of new innovations such as the provision of guidebooks for the use of e-procurement applications and even socialization using mass media so that the procurement of goods and services can achieve a level of transparency.
\end{abstract}

Keywords: Transparency, LPSE, E-Procurement.

\section{Introduction}

Transparency is one of the dimensions in realizing good governance [1]. Transparency can be interpreted as a process of openness in conveying information or administration activities of the government. This aims to increase public trust and participation in guarding government activities, especially in public services.

One of the highlights and criticism of the administration of government is public service. Among them are the procurement of goods and services. [2] explained that there are at least three reasons why the procurement of goods and services is a sensitive activity, namely: (a) having a relevant economic impact, (b) being relevant for government public services, and (c) being able affect the competitiveness and welfare of citizens. Therefore, the government must be able to create a transparent system in the procurement of goods and services. 
Problems in the procurement of goods and services in government institutions are quite crucial and there are indications of corruption. Based on data released by Indonesia Corruption Watch (ICW), at least it was confirmed from the results of ICW's observations in 2017, of which a total of 576 corruption cases were handled by law enforcement officials, in fact 42 percent or 241 cases were related to corruption in the procurement of goods and services. That number shows an upward trend compared to 2016 which only amounted to 195 corruption cases [3].

Based on the data above, it can be concluded that there are still many acts of corruption in procurement of goods and services in government institutions. Therefore, to reduce these problems the government needs to innovate to integrate technology in the implementation of the procurement of goods and services. This innovation is known as electronic procurement (eprocurement).

E-procurement is an internet-based self-service application that fully automatically simplifies transactions between buyers and suppliers and provides key information for strategic analysis [4]. All activities related to the implementation of procurement of goods and services are based on electronics, avoiding corruption.

One city in Aceh Province that has implemented an e-procurement system is the Banda Aceh City Government. In 2013, there were three cities that received special monitoring from ICW, namely Denpasar City, Banda Aceh City and Blitar District. These three regions are indicated by irregularities in the procurement of goods and services [5].

Based on the explanation from ICW, Banda Aceh City found indications of deviation from the process of procurement of goods and services electronically. In addition, also reported by the Daily Serambi media, that the Banda Aceh District Attorney detained four suspects for alleged corruption in the procurement of a modern fire engine (damkar) for Rp. 17.5 billion belonging to the Banda Aceh City Government [6].

Transparency studies in the procurement sector of goods and services are very urgent to carry out research, because there are still many frauds leading to corruption. Thus, this study can provide recommendations on problems in the procurement of goods and services in the Banda Aceh City Government, in realizing transparent and free governance indications of corruption. This study uses indicators of transparency proposed by [7] namely: (a) Provision of clear information about procedures; (b) Ease of access to information; (c) Compile a complaint mechanism if there are rules that are violated; (d) Increasing the flow of information through collaboration with mass media and non-government institutions; (e) Access to accurate and timely information.

\section{Research Methodology}

This study uses a descriptive qualitative research approach. The technique of collecting data was carried out in the form of observation, interviews and documentation studies [8]. While the focus of this research is the Office of Electronic System Procurement Services (LPSE), Banda Aceh City, Aceh Province.

\section{Discussion}




\subsection{The Implementation of E-Procurement in the Procurement of Goods and Services in the LPSE of Banda Aceh City}

The implementation of e-procurement in the city of Banda Aceh began in 2009 through the Banda Aceh Mayor Regulation Number 5 of 2009 concerning the Electronic Procurement Service Unit of the Banda Aceh City Government, which was later revised by Mayor Regulation Number 1 of 2011 [9]. The beginning of the establishment of e-procurement in the city of Banda Aceh because seeing procurement manually was more difficult and took a long time and had the potential for fraud both on the part of the provider and the committee which led to criminal acts of corruption.

The policy for the procurement of goods and services electronically in Banda Aceh City was strengthened by the issuance of Presidential Regulation Number 54 of 2010 concerning Government Procurement of Goods and Services. The Presidential Regulation explained that the implementation of electronic goods and services is expected to increase accountability, transparency, open opportunities for businesses micro, small and medium and competitive businesses. In achieving this goal, it is necessary to involve the government sector as the executor of procurement activities, private sector as a supplier in construction, and the community as a consumer group.

Every auction participant must enter the auction process electronically, there are steps or instructions that must be followed by several parties related to this auction activity, especially companies that take part in the tender. The flow of the auction process can be seen in the picture below:

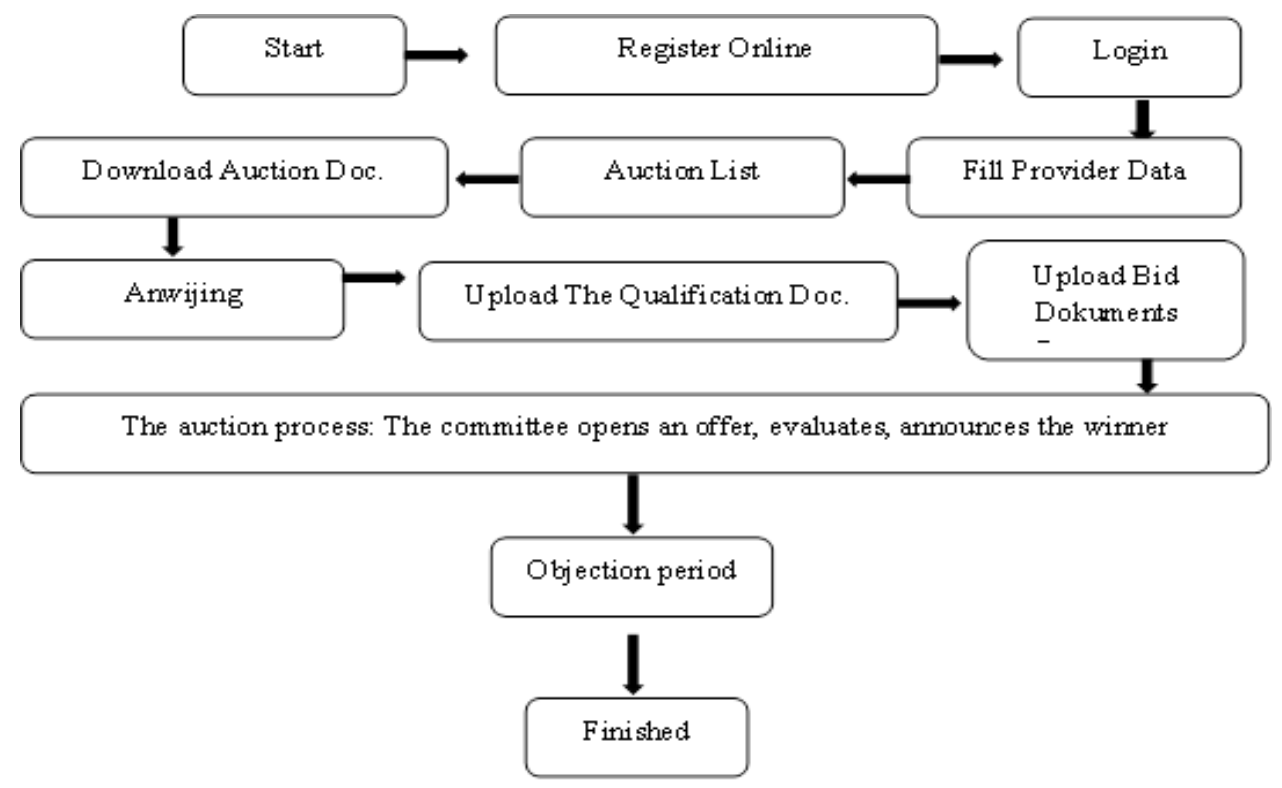

Figure 1. Provider Process Flow

Source: LKPP, Guidelines for Using SPSE 4.1 in 2018

The above flow describes the auction mechanism organized by the Banda Aceh City Government. Registration is done online, by logging in, then participants are required to fill in 
complete data. After filling in the data, participants participate in the auction to upload important documents related to auction requirements. Then the process opens offers, evaluations and announcements of auction winners.

\subsection{Transparency of Procurement of Goods and Services through E-Procurement at LPSE in Banda Aceh City}

Procurement of goods and services in government institutions is still gaining attention from the public. This is the number of cases of corruption caused by the procurement of goods and services. The government has an important role in creating transparency in the procurement of goods and services. Through the E-Procurement policy, it is expected to create a transparent principle in the governance sector.

Krina, (2003) explained that there were indicators of transparency, in this study the researchers used the indicators put forward by Krina, namely:

\subsubsection{There is clear information about the procedure}

Procurement of goods and services is the first step for partners to participate in an electronic auction. The existence of healthy competition, the establishment of justice and implementation in accordance with the rules, because the needs of providers relating to information and ease of access to information go well, in accordance with the expectations and the establishment of good cooperation between providers and the committee.

Information on procedures that have been issued in the application of electronic goods and services procurement at the Banda Aceh City LPSE is contained in the Banda Aceh Mayor Regulation No. 1 of 2011 concerning Electronic Procurement Services of Banda Aceh City. The Standard Operating Procedure (SOP) includes from registration to:

(a) registration and verification of SPSE users;

(b) SPSE usage services;

(c) handling problems (error handling);

(d) maintenance and security of SPSE infrastructure;

(e) maintenance of SPSE performance and capacity;

(f). Electronic document archiving (backup file)

The scope of clear information about the LPSE procedure is clearly in accordance with the Banda Aceh City Administration and there are no problems faced by partners regarding procedural information. However, monitoring and evaluation needs to be carried out to improve the quality of LPSE services in Banda Aceh City.

\subsubsection{Ease of access to information}

Ease of access to information related to administration and technical procurement of goods and services aims to create healthy competition between partners and avoid indications of corruption. All forms of information can be visited through the Banda Aceh City LPSE website. (https://lpse.bandaacehkota.go.id/eproc/).

Access to information in the auction of goods and services is effective and can be accessed anytime and anywhere. The ease of access to information in online auctions is very helpful for partners. So, partners do not require the office to find information related to the 

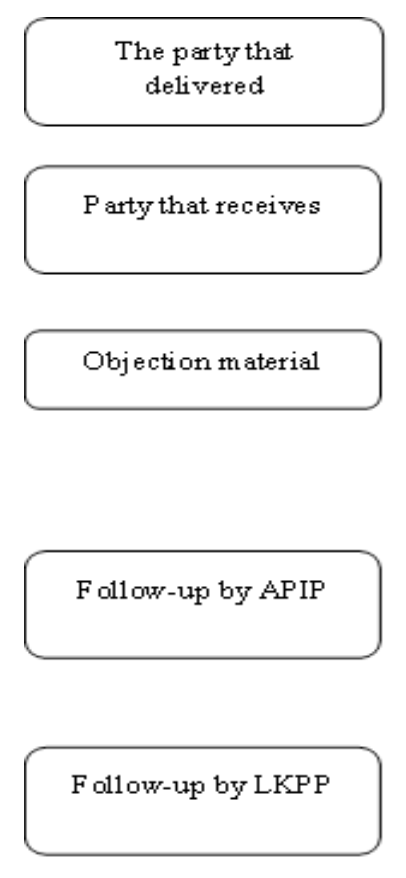

F ollow-up by authorized institutions

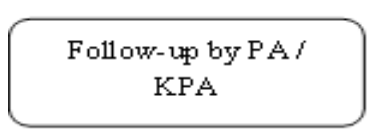

Follow-up by the minister / head of the institution/ head of the agency

Follow-up by the regional head

1. Provider of goods/ services

2. community

APIP and/or LKPP

1. Procechure deviation

2. KKN

3. Competition is not healthy

1. Report to the leader ship

2. Report to the competent authority with the approval of the Minister / head of the institution/ re gional head / institutionleader if there is an indication of $\mathrm{KKN}$

Convey opirions and / or recomm endations to APIP

1. If there is an indication of $\mathrm{KKN}$

2. Can be followed up after the contract is signed

Stating the auction failed if the objection was proven correct

Stating that the auction failed if the complaint involving KPA was proven correct

Stating the auction failed if the objection involving PA/ KPA was proven correct

Figure 2. Phases of Objection

Source: Presidential Regulation No. 54 of 2010 Article 117

auction but can be accessed through the website. Just as there was a change in the objection schedule, the change was immediately informed to the partner's e-mail on the tender. Such a model has facilitated partners to access information so that there is openness between providers and procurement committees for goods and services in the Banda Aceh City Government.

\subsubsection{The existence of a Complaint Mechanism if there is a Violated Regulation}


This complaints mechanism is a government effort to improve the quality of services and improve the procurement process electronically so that justice can be achieved by providers. In addition, the committee in this case was more responsible in the auction process as long as the committee was able to provide the right answer for the refuters. The mechanism that must be passed by the provider to make complaints or objections in figure 2 .

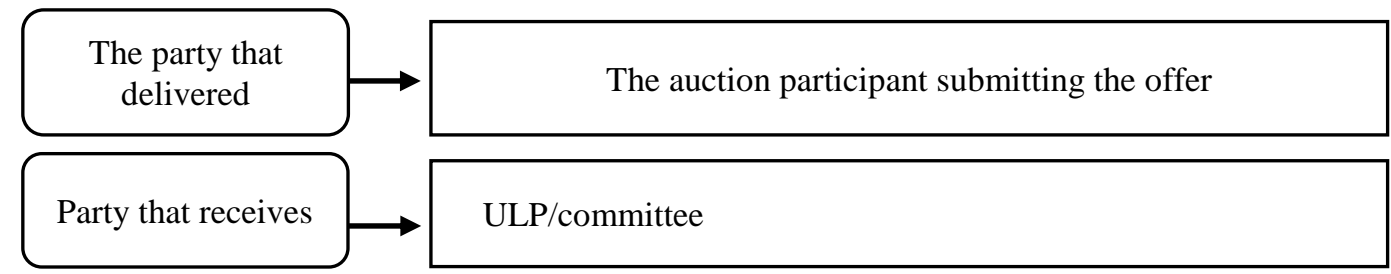

\begin{tabular}{|c|c|}
\hline $\begin{array}{c}\text { Disclaimer } \\
\text { material }\end{array}$ & $\begin{array}{l}\text { 1. Procedure deviation } \\
\text { 2. Specific engineering } \\
\text { 3. Abuse of authority }\end{array}$ \\
\hline
\end{tabular}
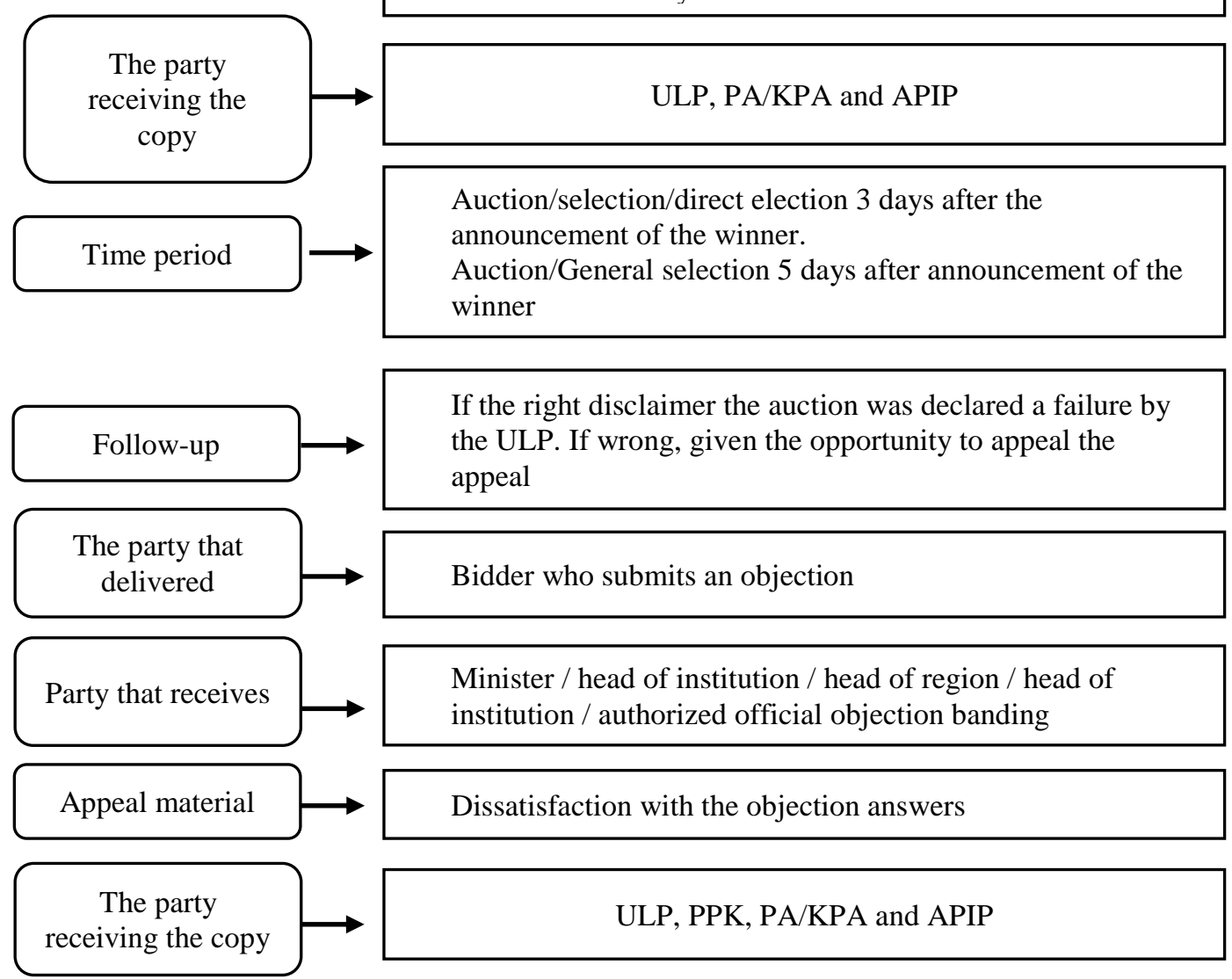

Figure. 3 Stages of Disclaimer

Source: Presidential Regulation No. 54 of 2010 Article 81 and 82. 
Based on the scheme above, there is a mechanism for complaints about problems in the procurement of goods and services in Banda Aceh City. Through this Electronic Auction Service (LPSE), all partner needs can be easily fulfilled. The established justice will attract attention to providers to continue to be partners.

\subsubsection{Collaboration with Media or Non-Government Institutions.}

Collaboration with non-government institutions in the procurement of goods and services electronically so far there is no form of cooperation. So far, LPSE has only made the company a work partner. LPSE is only a system that is run for the process of procurement of goods and services electronically.

Collaboration is carried out only on government institutions, such as the KPK, BAPPENAS, and the Ombudsman. This aims to detect indications of corruption in the process of auctioning goods and services electronically in Banda Aceh City. So is the case with the media, since the auction of electronic goods and services has been implemented, there is no longer cooperation with the media. All information related to the auction is informed online.

\subsubsection{Access to Accurate and Timely Information}

One of the advantages of implementing e-procurement is that it can provide updated and rational information. This is in accordance with one of the objectives of the establishment of procurement of government goods / services electronically, which is to fulfill real time access to information needs. All information relating to the time specified by the committee can be seen on the Banda Aceh City website (https://lpse.bandaacehkota.go.id/eproc/). When the auction phase starts, the deadline for each stage of the auction, the schedule for the upload deadline and the opening of the bidding documents are determined by the LPSE of Banda Aceh City [10].

\section{Conclusion}

Based on the discussion above, it can be concluded as follows:

1. The electronic application of goods and services in the city of Banda Aceh has been implemented since the birth of the Regulation of the Mayor of Banda Aceh No. 1 of 2011 concerning Electronic Procurement Services of Banda Aceh City. Service innovation by adopting technology in the goods and services procurement sector has made a difference with the old system. Through the new system, it has provided considerable benefits. Among them are saving time and costs, opening opportunities and healthy competition between companies, and creating justice in the auction process.

2. Transparency in the process of procurement of goods and services in the LPSE of Banda Aceh City has not yet been fully realized. There is still no collaboration with the media or non-government institutions. This is because all information related to the auction has been submitted through the website

\subsection{Suggestions}

The suggestions are to build cooperation with mass media and non-government institutions, even though information related to the auction has been informed through the website. 
Collaboration between non-governmental institutions is highly recommended in democratic governments, especially with regard to auctions, in order to create transparency in government

\section{References}

[1] A. Farazmand, Sound governance: 2004.

[2] F. Bof, P. Previtali, and V. S. Felice, "National models of public ( e ) -procurement in Europe," vol. 2010, 2010.

[3] ICW, "Transparansi Pengadaan Pemerintah," 2018. [Online]. Available: https://antikorupsi.org/id/news/transparansi-pengadaan-pemerintah. [Accessed: 29-Apr-2019].

[4] R. D. Richardus Eko Indrajit, Electronic Procurement, no. C. 2012.

[5] ICW, "Catatan Korupsi Semester II tahun 2013," Darurat Pengadaan Barang dan Jasa, 2013. [Online]. Available: https://antikorupsi.org/sites/default/files/files/Berita/Darurat Pengadaan Barang dan Jasa - E-procurement.pdf. [Accessed: 27-Apr-2019].

[6] Serambinews.com, "KPK segel Ruang Kerja Gubernur Aceh dan ULP," 2018. [Online]. Available: http://aceh.tribunnews.com/2018/07/05/kpk-segel-ruang-kerja-gubernur-aceh-danulp. [Accessed: 29-Apr-2019].

[7] L. Krina, Indikator dan Tolak Ukur Akuntabilitas, Transparansi, dan Partisipasi. Jakarta, 2003.

[8] Sugiyono, Metode Penelitian Kombinasi (Mixed Methods). Bandung: Alfabeta, 2013.

[9] Peraturan Walikota Banda Aceh Nomor 1 tahun 2011 tentang Layanan Pengadaan Secara Elektronik Kota Banda Aceh.

[10] P. P. No, "tahun 2010 tentang Pengadaan barang," Jasa pemerintah, 54AD. 